\title{
PENGARUH PEMBERIAN JUS BUAH PEPAYA (Carica Papaya L) TERHADAP GAMBARAN HISTOPATOLOGIK FATTY STREAK PADA DINDING AORTA ABDOMINALIS TIKUS WISTAR JANTAN HIPERKOLESTEROLEMIK
}

\author{
Hendra Sutysna \\ Iskandar Japardi \\ Soekimin \\ Bagian Anatomi-Histologi Fakultas Kedokteran \\ Universitas Muhammadiyah Sumatera Utara, Universitas Sumatera Utara Medan \\ Email: drhendrasutysna@yahoo.co.id
}

\begin{abstract}
Papaya (Carica papaya L) is rich of antioxidants, such as betacarotene, which is a powerful antidote to reactive oxygen compound (ROS) and stimulates the body to convert toxic substances into harmless compounds. In atherosclerotic lesions, antioxidants inhibit the oxidation of LDL cholesterol and prevent the oxidative stress, therefore, reducing the vascular endothelial dysfunction. This study aimed to obtain the effect of papaya given orally on histopathological changes which was determined by numbers of foam cells and abdominal aortic wall thickness of male hypercholesterolemic wistar rats. This was an experimental study. Samples were 24 adult male wistar rats divided into five groups. The negative control group K1 was fed on standard diet for 2 weeks and the positive control group K2, each was fed on diet of egg yolks $5 \mathrm{mg} /$ day for 2 weeks. There were three treatment groups: P1, each was fed on papaya juice 2,6 g/day for 2 weeks; $\mathrm{P} 2$, each was fed on papaya juice 2,6 g/day for 4 weeks; and P3, each was fed on papaya juice $2,6 \mathrm{~g} /$ day for 6 weeks by using nasogastric tube. After the treatment period of each sample group, the wistar rats were decapitated, and then the levels of total cholesterol and LDL of blood serum were examined as well as the histopathological changes were identified. Data were analyzed by using Oneway-Anova test, followed by Post-Hoc test. The results showed that among P1, P2, and P3 groups there were reductions in the numbers of foam cells in the walls of the abdominal aorta and in the thickness of abdominal aortic wall compared to the K2. Conclusion: Papaya juice which was given orally for 2-4 weeks could reduce the histopathological changes of abdominal aortic walls of male hypercholesteremic wistar rats.
\end{abstract}

Keywords: papaya, antioxidant, hypercholesterolemic, histopathological changes, fatty streak

Abstrak: Pepaya (Carica papaya L) kaya akan antioksidan beta-karoten yang merupakan
penawar kuat untuk senyawa oksigen reaktif (ROS) dan berkemampuan menstimulasi tubuh
untuk mengubah substansi toksik menjadi senyawa yang tidak berbahaya. Pada lesi
aterosklerotik, antioksidan dapat menghambat oksidasi kolesterol LDL dan stres oksidatif
sehingga mengurangi terjadinya disfungsi endotel pembuluh darah. Penelitian ini bertujuan
untuk mengetahui efek pemberian jus buah pepaya secara oral terhadap gambaran
histopatologik yaitu jumlah sel busa dan ketebalan dinding pembuluh darah dari aorta abdo-
minalis tikus wistar jantan yang hiperkolesterolemik. Penelitian ini bersifat eksperimental
dengan rancangan Randomized Post-test Only Control Group Design. Sampel 24 ekor tikus
wistar jantan dewasa dibagi dalam 5 kelompok. Kelompok kontrol negatif K1 diberi diet
pakan standar selama 2 minggu dan kelompok kontrol positif K2 diberi diet kuning telur 5
mg/ekor/hari selama 2 minggu. Terdapat tiga kelompok perlakuan: P1 diberi jus pepaya 2,6
g/ekor/hari selama 2 minggu; P2 diberi jus pepaya 2,6 g/ekor/hari selama 4 minggu; dan P3 
yang diberi jus pepaya 2,6 g/ekor/hari selama 6 minggu melalui sonde hidung. Setelah masa perlakuan masing-masing kelompok, sampel didekapitasi, kemudian diukur kadar kolesterol total dan LDL serum darah, serta diidentifikasi gambaran histopatologik yaitu jumlah sel busa dan ketebalan dinding aorta abdominalis. Data dianalisis dengan uji Oneway- Anova dan dilanjutkan dengan uji Post-Hoc. Hasil penelitian menunjukkan bahwa pemberian jus buah pepaya 2,6 gram/ekor pada kelompok perlakuan P1, P2, dan P3 dapat menurunkan jumlah sel busa pada dinding aorta abdominalis dan ketebalan dinding aorta abdominalis tikus wistar jantan yang hiperkolesterolemik dibandingkan dengan kelompok kontrol positif K2. Simpulan: Pemberian jus pepaya per oral selama 2-4 minggu dapat menurunkan perubahan histopatologik dinding aorta abdominalis tikus wistar jantan yang hiperkolesterolemik.

Kata kunci: pepaya, antioksidan, hiperkolesterolemik, histopatologik, fatty streak.

Penyakit jantung, stroke, dan aterosklerosis merupakan penyakit yang mematikan dengan angka kejadian yang terus meningkat di seluruh dunia. Di Eropa diperhitungkan 20.000-40.000 orang dari 1 juta penduduk menderita penyakit jantung koroner (PJK). Organisasi Kesehatan Sedunia (WHO) dan Organisasi Federasi Jantung Sedunia (World Heart Federation) memrediksi penyakit jantung akan menjadi penyebab utama kematian di negara-negara Asia pada tahun 2010. Saat ini, sekurangkurangnya $78 \%$ kematian global akibat penyakit jantung terjadi pada kalangan masyarakat miskin dan menengah. Di negara berkembang dari tahun 1990 sampai 2020, angka kematian akibat PJK akan meningkat $137 \%$ pada laki-laki dan $120 \%$ pada perempuan, sedangkan di negara maju peningkatannya lebih rendah yaitu $48 \%$ pada laki-laki dan $29 \%$ pada perempuan. Di tahun 2020 diperkirakan penyakit kardiovaskuler menjadi penyebab kematian 25 orang setiap tahunnya. ${ }^{1}$

Kolesterol masih merupakan topik yang menarik untuk diteliti karena sering dikaitkan dengan beberapa penyakit mematikan antara lain PJK. Telah diketahui bahwa penyebab PJK multi-faktor, di antaranya ialah dislipidemia dan peningkatan oksidasi kolesterol low density lipoprotein (LDL). ${ }^{2}$

Pepaya merupakan salah satu buah tropis yang kaya dengan antioksidan, antara lain vitamin $\mathrm{C}$ dan beta-karoten yang merupakan penawar kuat terhadap senyawa oksigen reaktif (ROS) dan menstimulasi kemampuan tubuh untuk mengubah substansi toksik menjadi senyawa yang tidak berbahaya.,

\section{LIPID}

Lipid terdiri dari lemak netral, dikenal juga sebagai trigliserida, fosfolipid, kolesterol, dan beberapa senyawa lainnya. ${ }^{5}$ Lipid diangkut dalam plasma sebagai lipoprotein. Empat kelompok utama lipoprotein yang telah diidentifikasi yaitu kilomikron, very low density lipoprotein (VLDL), low density lipoprotein (LDL), dan high density lipoptotein (HDL). ${ }^{6}$ Lipoprotein berperan besar dalam pengangkutan lemak dari saluran cerna ke seluruh sel jaringan tubuh dan dari sel jaringan tubuh ke hati. ${ }^{7}$

Hiperlipidemia adalah terjadinya akumulasi berlebih salah satu atau lebih lipid utama plasma dan merupakan manifestasi kelainan metabolisme (produksi berlebihan) atau transportasi lipid. Dalam klinis, hiperlipidemia dinyatakan sebagai hiperkolesterolemia, hipertrigliserida, atau kombinasi keduanya. ${ }^{8}$

\section{Low density lipoprotein (LDL)}

LDL mengandung kolesterol dan fosfolipid yang cukup tinggi serta merupakan lipoprotein yang mengangkut kolesterol terbesar untuk disebarkan ke seluruh jaringan tubuh dan pembuluh darah. LDL sering disebut kolesterol jahat karena efeknya yang aterogenik (mudah melekat pada dinding pembuluh darah), sehingga dapat menyebabkan penumpukan lemak dan penyempitan pembuluh darah (aterosklerosis). Kadar LDL di dalam darah 
sangat tergantung dari lemak jenuh yang masuk. Semakin banyak lemak jenuh yang masuk, semakin menumpuk pula LDL karena LDL merupakan lemak jenuh yang tidak mudah larut.

\section{Radikal bebas dan LDL oksidasi}

Menurut Mc Kee, beberapa penelitian sudah membuktikan efek berbahaya yang ditimbulkan oleh reaksi kimia dari radikal bebas yaitu atom atau molekul yang tidak stabil atau sangat reaktif karena mengandung satu atau lebih elektron tidak berpasangan pada orbit terluarnya. Untuk mencapai kestabilan atom atau molekul, radikal bebas akan bereaksi dengan molekul disekitarnya untuk memperoleh pasangan elektron. Oksigen dapat menerima elektron tunggal dan membentuk molekul tak stabil yang dikenal dengan molekul reactive oxygen species (ROS) yaitu antara lain antara lain radikal superoksid (O2), radikal hidroksil (HO) dan singlet oksigen $(\mathrm{O})$. Dalam keadaan normal, pada organisme hidup, pembentukan ROS dijaga seminimal mungkin oleh mekanisme pertahanan antioksidan. Kondisi tertentu dimana mekanisme antioksidan terhalang atau menjadi tak seimbang, akan menyebabkan kerusakan dalam jaringan, yang dikenal secara kolektif sebagai stres oksidatif. ${ }^{9}$

\section{Antioksidan}

Antioksidan merupakan agen protektif yang menonaktifkan ROS sehingga dapat mencegah kerusakan oksidatif. Antioksidan yang secara alami berada dalam sel-sel manusia (endogen) antara lain superoksida dismutase (SOD), katalase (CAT), dan glutation peroksidase (GPx). ${ }^{10}$

GPx berperan dalam perlindungan terhadap peroksidase lipid. Pada keadaan stres oksidatif kerja glutationeperoksidase akan meningkat. ${ }^{10}$ Betakaroten merupakan bentuk paling aktif secara biologis dan merupakan salah satu karotenoid yang berperan dalam perlindungan terhadap stres oksidatif. Sumber utama betakaroten ialah sayur dan buah. ${ }^{10,11}$

\section{Pembentukan lesi aterosklerotik}

Aterosklerosis adalah penyakit akibat terbentuknya plak di dinding arteri besar, sehingga mempersempit lumen pembuluh darah dan mengakibatkan aliran darah terganggu dan menurunkan elastisitas pembuluh darah. Plak terdiri dari sel otot polos, jaringan ikat, lemak, dan kotoran yang tertimbun dalam intima dinding arteri. $^{3}$

Lesi aterosklerosis awal berupa fatty streak, yaitu penumpukan lemak pada daerah subintima yang tampak sebagai daerah berwarna kekuningan pada permukaan dalam arteri, umumnya berbentuk bulat dengan diameter $\theta, 1 \mathrm{~mm}$ atau berbentuk guratan dengan lebar 1-2 $\mathrm{mm}$ dan panjang sampai $1 \mathrm{~cm}$. Secara mikroskopik, fatty streak ditandai dengan pengumpulan sel-sel busa (foam cells) di daerah subintima. Hiperlipidemia kronik dapat menyebabkan cedera toksik pada selsel endotel karena peningkatan LDL yang teroksidasi dan kolesterol. ${ }^{12}$ LDL teroksidasi bersifat antigenik sehingga terjadi reaksi pembentukan antibodi yang mengikatnya dan membentuk kompleks imun. $^{13}$

\section{METODE PENELITIAN}

Penelitian ini bersifat eksperimental (true experimental design) dengan Randomized Post-test Only Control Group Design yang menggunakan kelompok kontrol dan kelompok perlakuan dengan randomisasi sederhana. Penelitian dilakukan di Laboratorium Patologi Anatomi Fakultas Kedokteran Universitas Sumatera Utara dan Laboratorium Biologi Fakultas Matematika dan Ilmu Pengetahuan Alam (FMIPA) Universitas Sumatera Utara (USU) Medan selama 8 minggu.

Sampel penelitian 25 ekor tikus wistar jantan yang dipilih dengan teknik acak sederhana. Sampel dikelompokkan atas 5 kelompok, yaitu kelompok I sebagai kontrol negatif (K1) dan kelompok II (K2) sebagai kontrol positif, sedangkan kelompok III (P1), IV (P2), dan V (P3) 
ialah kelompok perlakuan. Penentuan besar sampel ditentukan dengan rumus Federer.

Kelompok K1 diberi diet standar selama 2 minggu kemudian pada hari ke-15 dilakukan pemeriksaan kolesterol total darah dan dikapitasi untuk melihat gambaran dinding aorta yang dianggap normal. Kelompok K2 setelah diinduksi dengan adrenalin, diberi pakan standar dan diet kuning telur saja selama 2 minggu kemudian diberi pakan standar selama dua minggu lagi. Pada hari ke-29 dilakukan pemeriksaan kolesterol total darah dan didekapitasi untuk melihat gambaran lesi aterosklerosis. Kelompok P1 setelah diinduksi dengan adrenalin, diberi pakan standar dan diet kuning telur selama dua minggu lalu dilakukan pemeriksaan kolesterol total darah, kemudian diberi diet standar dan jus buah pepaya selama 2 minggu dan pada hari ke-29 didekapitasi untuk melihat gambaran lesi aterosklerosis. Kelompok P2 setelah diinduksi adrenalin, diberi pakan standar dan diet tinggi kolesterol selama dua minggu lalu dilakukan pemeriksaan kolesterol total darah kemudian diberi pakan standar dan jus buah pepaya selama 4 minggu dan pada hari ke-43 didekapitasi untuk melihat gambaran lesi aterosklerosis. Kelompok P3 setelah diinduksi adrenalin, diberi pakan standar dan diet kuning telur selama dua minggu lalu dilakukan pemeriksaan kolesterol total darah kemudian diberi diet standar dan jus buah pepaya selama 8 minggu dan pada hari ke-57 didekapitasi untuk melihat gambaran lesi aterosklerosis.

Data yang dikumpulkan ialah jumlah sel busa dan ukuran ketebalan dinding aorta abdominalis. Setelah masa perlakuan, masing-masing kelompok sampel didekapitasi, kemudian diukur kadar kolesterol total dan LDL darah, serta diamati gambaran histopatologik sel busa dan ketebalan dinding aorta abdominalisnya.

Hasil uji parametrik dengan metode analitik untuk sampel $\mathrm{n}<50$ menggunakan parameter Shapiro-Wilk. ${ }^{14}$

\section{HASIL PENELITIAN}

Jumlah sel busa pada dinding aorta abdominalis tikus wistar jantan

Hasil pengukuran jumlah sel busa pada dinding aorta abdominalis tikus wistar jantan pada semua kelompok sampel penelitian ditampilkan pada Gambar 1, dan diperoleh perbedaan rerata jumlah sel busa tiap kelompok sampel penelitian.

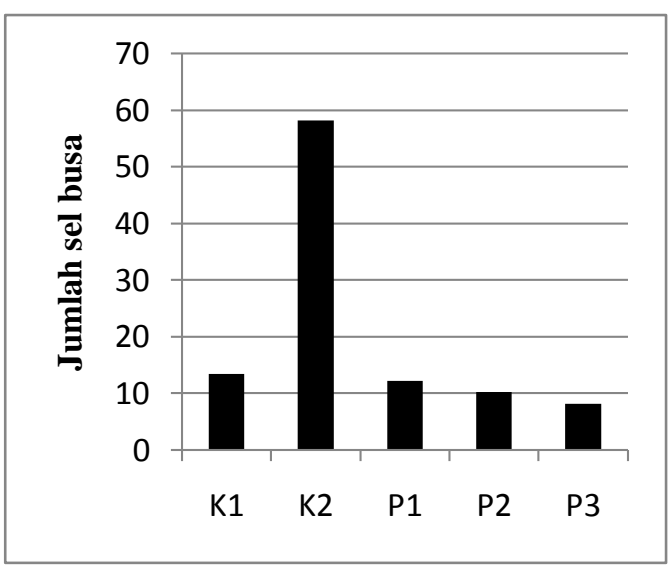

Gambar 1. Grafik hasil pemeriksaan jumlah sel busa tikus wistar jantan pada semua kelompok sampel penelitian. Keterangan: K1 kontrol (-), K2 kontrol (+), P1 perlakuan 1, P2 perlakuan 2, dan $\mathrm{P} 3$ perlakuan 3 , dengan nilai $P<0,05$ (berbeda bermakna).

Pada uji normalitas dan homogenitas data, ternyata data jumlah sel busa dinding aorta abdominalis terdistribusi normal dan variansinya homogen, sehingga tidak perlu dilakukan transformasi data. Data memenuhi syarat pengujian parametrik one way Anova pada level 5\%. Hasil uji menunjukkan perbedaan bermakna antara perlakuan penelitian $(P<0,05)$.

\section{Ketebalan dinding aorta abdominalis tikus wistar jantan}

Gambar 2 memperlihatkan hasil pengukuran ketebalan dinding aorta abdominalis tikus wistar jantan pada semua kelompok sampel penelitian. 
Terdapat perbedaan rerata ketebalan dinding aorta abdominalis tiap kelompok sampel penelitian. Pada uji normalitas dan homogenitas data, ternyata data ketebalan dinding aorta abdominalis terdistribusi normal tetapi variansi data tidak homogen, sehingga dilakukan transformasi data.

Hasil transfromasi data memperlihatkan data terdistribusi normal tetapi tidak homogeni sehingga data diuji dengan non-parametrik Kruskal Wallis pada level 5\%. Hasil uji menunjukkan perbedaan bermakna antara perlakuan penelitian $(P$ $<0,05)$, sehingga dilanjutkan dengan uji Mann-Whitney yang melihat perbedaan masing-masing perlakuan.

\section{Gambaran histopatologik tebal dinding aorta}

Pengaruh pemberian jus pepaya terhadap ketebalan dinding aorta abdominalis dapat dilihat pada perbandingan $\mathrm{P} 1$,
P2, dan P3 dengan kontrol positif. Terdapat perbedaan yang nyata $(P<0,05)$ antara kontrol (+) dengan P1, P2, dan P3.

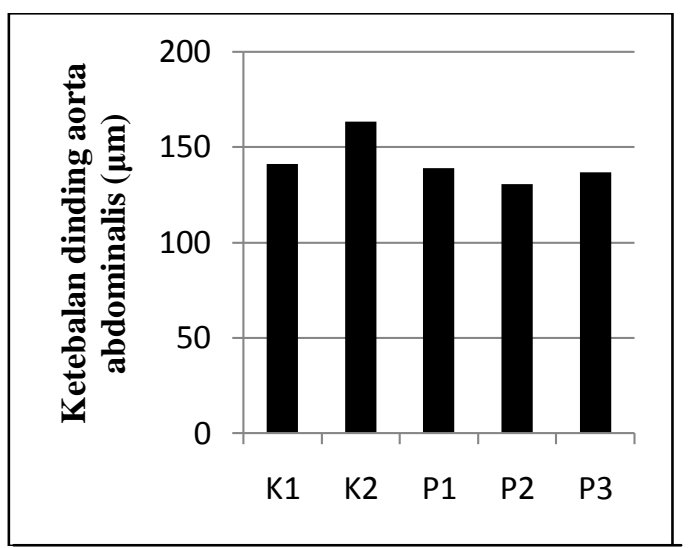

Gambar 2. Grafik hasil pengukuran tebal dinding aorta abdominalis $(\mu \mathrm{m})$ tikus wistar jantan pada semua kelompok sampel penelitian. Keterangan: K1 kontrol (-), K2 kontrol (+), P1 perlakuan 1, P2 perlakuan 2, dan P3 perlakuan 3 , dengan nilai $P<0,05$ (berbeda bermakna).

\section{Gambaran histopatologik}

\section{Gambaran histopatologik sel busa pada dinding aorta abdominalis}
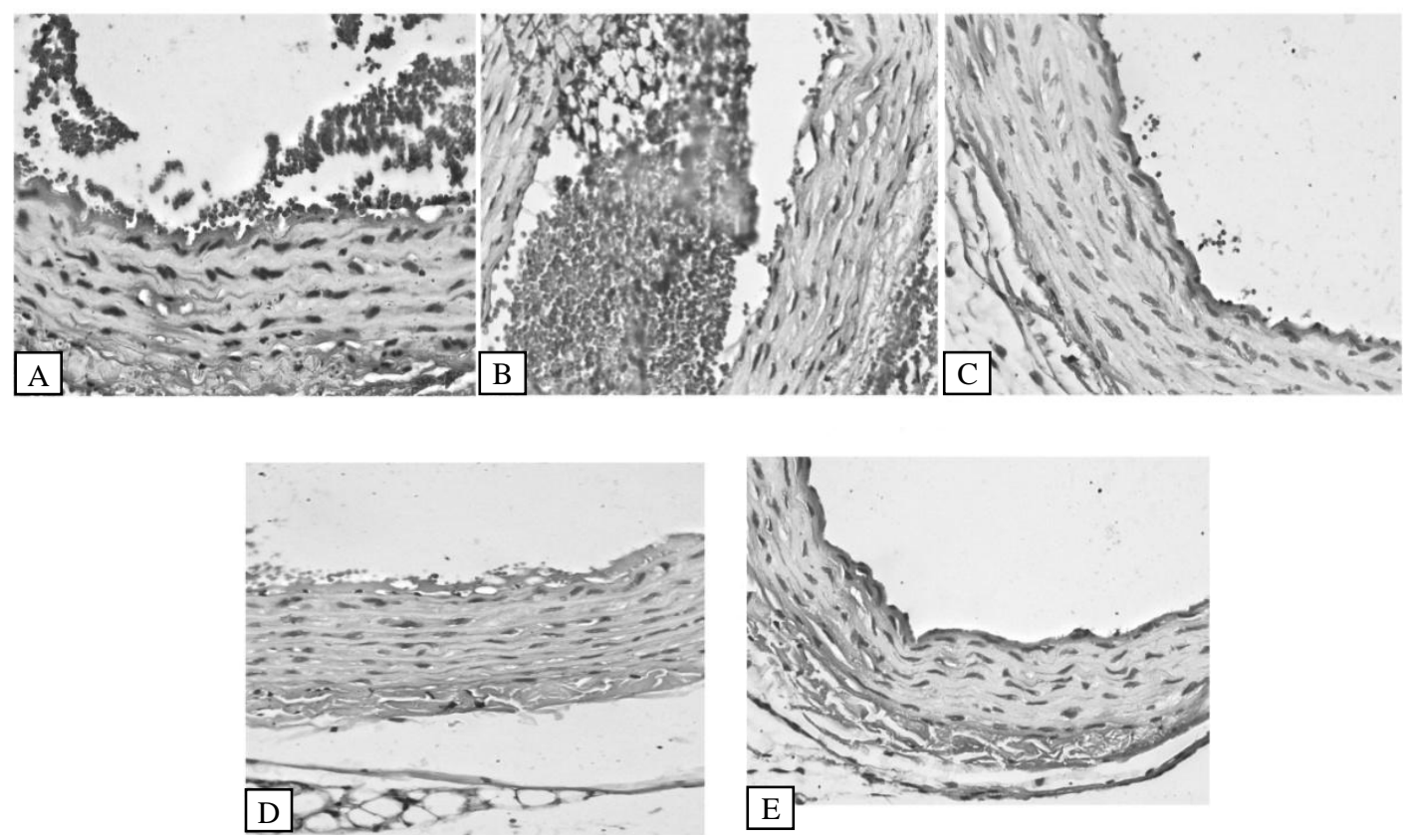

Gambar 3. Gambaran histopatologik sel busa pada dinding aorta abdominalis dari semua kelompok sampel penelitian (HE-400x). A, Kelompok K1; B, Kelompok K2; C, Kelompok P1; D, Kelompok P2; E, Kelompok P3. 

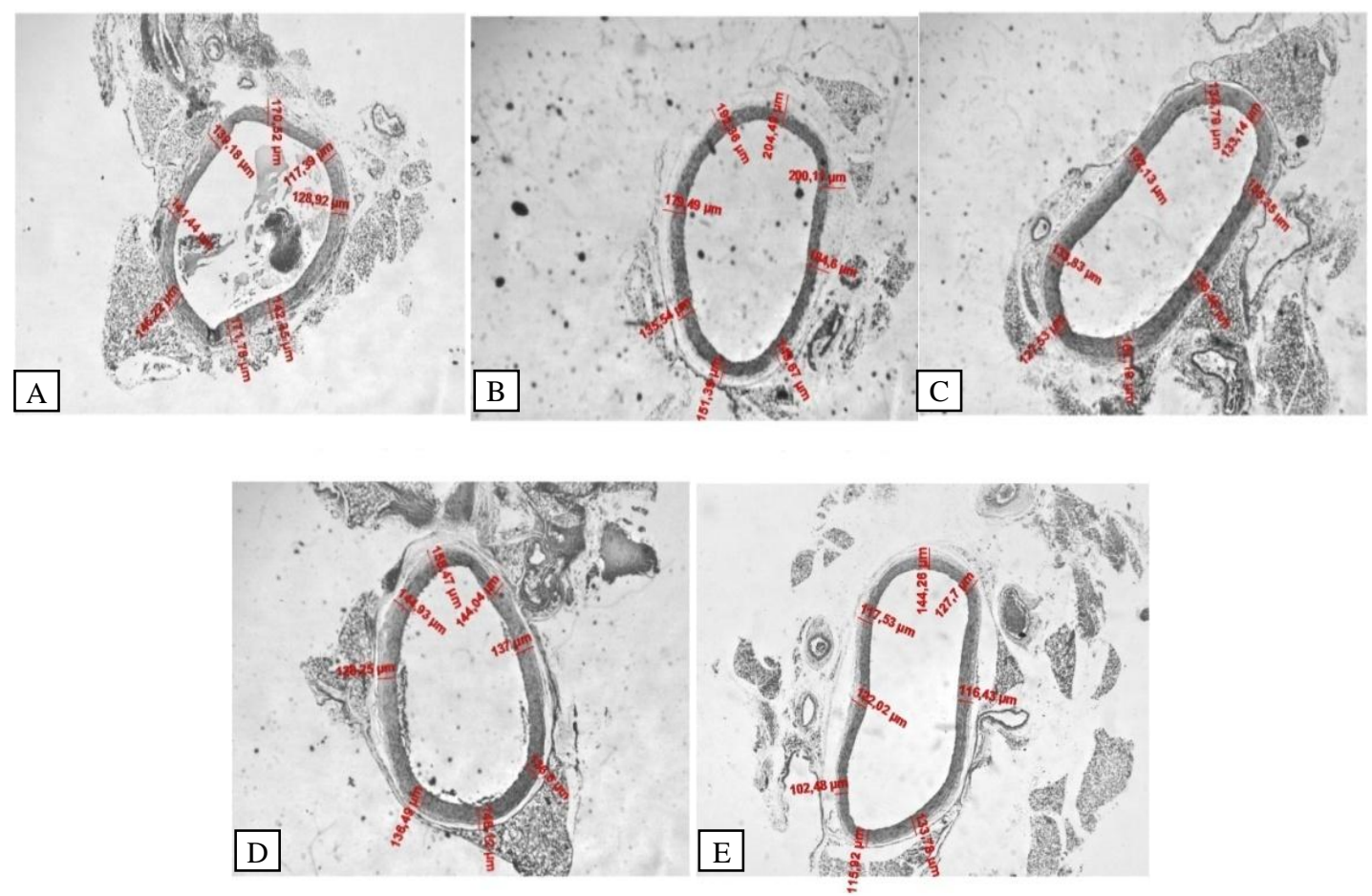

Gambar 4. Gambaran histopatologik ketebalan dinding aorta abdominalis semua kelompok sampel penelitian (HE-400x). A, Kelompok K1; B, Kelompok K2; C, Kelompok P1; D, Kelompok P2; E, Kelompok P3.

\section{BAHASAN}

\section{Jumlah sel busa pada dinding aorta abdominalis tikus wistar jantan}

Hasil penelitian ini memperlihatkan bahwa rerata jumlah sel busa pada dinding aorta abdominalis meningkat pada kelompok kontrol positif dan menurun secara bermakna pada kelompok perlakuan yang diberi asupan jus pepaya (P1, 2, dan 3). Tingginya kadar kolesterol LDL meningkatkan kemungkinan terjadi-nya reaksi oksidasi LDL oleh radikal bebas. LDL teroksidasi bersifat antigenik sehingga terjadi reaksi pembentukan antibodi yang mengikatnya dan membentuk kompleks imun karena banyaknya monosit yang masuk ke sub intima. Kompleks imun LDL teroksidasi akan difagositosis oleh makrofag yang mempunyai reseptor untuk mengikat kompleks imun LDL-oks sehingga fagositosis semakin mudah dan memicu pembentukan sel busa. ${ }^{13}$

Pada penelitian ini digunakan jus buah papaya yang kaya antioksidan, salah satunya ialah betakaroten yang merupakan bentuk paling aktif secara biologis. Konsumsi betakaroten secara rutin untuk masa waktu tertentu dapat memberikan asupan antioksidan didalam tubuh yang tentunya berdampak juga pada oksidasi LDL yang tinggi didalam darah. ${ }^{11}$

Menurut Japardi. ${ }^{12}$ keadaan hiperkolesterolemi menyebabkan meningkatnya adhesi monosit ke dinding endotel. Monosit yang menempel pada sel-sel endotel menyusup di antara sel-sel tersebut dan mengambil tempat di daerah subendotel, selanjutnya berrubah menjadi scavenger cell dan berdiferensiasi menjadi makrofag. Makrofag berfungsi memfagositosis dan membersihkan lemak terutama LDL teroksidasi melalui reseptor khusus yang disebut reseptor scavenger. Sel scavenger ini kemudian menjadi sel busa yang merupakan cikal bakal fatty streak.

Jumlah sel busa pada dinding aorta abdominalis tikus wistar kelompok P1, P2 dan P3 berbeda bermakna, dan lebih sedikit dibanding jumlah sel busa kelompok K2. 
Hal ini diduga karena LDL tidak banyak teroksidasi oleh oksidan bebas akibat banyaknya antioksidan betakaroten dari buah pepaya yang mengikat oksidan bebas tersebut, sehingga terbentuknya LDL oksidasi ditekan.

\section{Ketebalan dinding aorta abdominalis tikus wistar jantan}

Pada aterosklerosis terbentuk plak yang terdiri dari sel otot polos, jaringan ikat, lemak, dan kotoran yang tertimbun dalam intima dinding arteri. Pada dinding arteri besar plak mempersempit lumen pembuluh darah, dan mengakibatkan aliran darah terganggu, dan menurunkan elastisitas pembuluh darah. ${ }^{2}$

Dari hasil pengukuran terlihat bahwa rerata ketebalan dinding aorta abdominalis kelompok $\mathrm{K} 1$ meningkat tetapi menurun pada kelompok P1, P2, dan P3. Pertambahan jumlah sel busa dalam tunika intima mungkin meningkatkan penebalan dinding pembuluh darah cenderung ke arah lumen sehingga terjadi penyempitan lumen pembuluh darah tersebut.

Tebal dinding aorta abdominalis pada kelompok P1, P2, dan P3 ternyata berbeda bermakna dimana ketebalan dinding aorta abdominalisnya lebih rendah dibanding kelompok K2. Hal ini diduga oleh karena sel busa tidak banyak terbentuk, sehingga mengurangi progresifitas penebalan dinding pembuluh darah akibat fibrous plaque.

\section{SIMPULAN}

Berdasarkan hasil penelitian dan bahasan, dapat disimpulkan bahwa pemberian jus buah pepaya 2,6 g/ekor/hari selama 2 minggu, 4 minggu, dan 6 minggu dapat memperlihatkan gambaran histopatologik berupa penurunan jumlah sel busa dan ketebalan dinding aorta abdominalis tikus wistar jantan yang hiperkolesterolemik.

\section{DAFTAR PUSTAKA}

1. World Health Organization. WHO Report 2000. Genewa: WHO, 2010. [Cited 2012 Jun 20]. Available from: http://www.scribd.com/doc/83124818/ Chronic Disease incidence figures are there in Indonesia and in the world.

2. Schoen FJ, Cotran RS. Pembuluh darah. In: Kumar V, Cotran RS, Robbins SL. Buku Ajar Patologi Robbins Vol 2 (Edisi 7). Jakarta: EGC, 2007; 366-86.

3. Aravind G, Bhowmik D, Duraivel $S$. Traditional and medicinal uses of carica papaya. Journal of Medicinal Plants Studies. 2013(1):7-15.

4. Tim redaksi Vitahealth. Seluk beluk Food Suplemen. Jakarta: PT Gramedia Pustaka Umum, 2004.

5. Guyton AC. Buku Ajar Fisiologi Kedokteran. Jakarta: Kedokteran EGC, 2007.

6. Murray RK, Granner DK, Mayes PA, Rodwell VW. In: Bani AP, Sikumbang TMN, editors. Biokimia Harper (Edisi 25). Jakarta: EGC, 2009; p. 128.

7. Tirtawanata TC. Makanan dalam Perspektif Al-Qur'an dan Ilmu Gizi. Jakarta: Balai Penerbit FKUI, 2006.

8. Sherwood L. Fisiologi Manusia dari Sel ke Sel (Edisi 2). Penerjemah: Pendit BU. Jakarta: EGC, 2003.

9. Mc Kee T, Mc Kee JR. 2003. Aerobic metabolism II: electron transport and oxidative phosphorylation In: Biochemistry the Molecular Basis of Life (Third Edition). New York: Mc Graw-Hill, 2003.

10. Small DM. In: Stipanuk MH, editor. Biochemical and Physiological Aspects of Human Nutrition. Philadelphia: WB Saunders, 2000: p. 43-71.

11. Juergen GE. Lycopene, $\beta$ - karoten, and colorectal adenomas. Am J Clin Nutr. 2003;78:1219-24.

12. Kumalasari ND. Pengaruh berbagai dosis filtrat daun putri malu (Mimosa pudica) terhadap kadar gula darah pada tikus (Rattus norvegicus). [Skripsi]. Medan: FKIP UMM, 2005

13. Japardi I. Patomekanisme stroke infark aterotrombotik [Tesis]. Medan: FK USU, 2003; p. 5-8. 
186 Jurnal Biomedik (JBM), Volume 6, Nomor 3, November 2014, hlm. 179-186

14. Suryohudoyo P. Kapita Selekta Ilmu Kedokteran Molekuler. Jakarta: CV Sagung Seto, 2000.
15. Devinda. Panjang Umur dengan Kontrol Kolesterol dan Asam Urat. Yogyakarta: Penerbit Cahaya Atma Pustaka, 2012. 